\title{
ANALISIS PENGARUH UKURAN DROP PANEL TERHADAP GESER PONS DAN MOMEN LENTUR PADA FLAT SLAB
}

\author{
Handexsen $^{1}$ dan Edison Leo ${ }^{2}$ \\ ${ }^{1}$ Program Studi Sarjana Teknik Sipil, Universitas Tarumanagara, Jl. Letjen S. Parman No.1 Jakarta \\ Email:dexsen67@gmail.com \\ ${ }^{2}$ Program Studi Sarjana Teknik Sipil, Universitas Tarumanagara, Jl. Letjen S. Parman No.1 Jakarta \\ Email: edisonl@ft.untar.ac.id
}

\begin{abstract}
ABSTRAK
Pelat lantai termasuk elemen struktur yang selalu dijumpai di setiap proyek konstruksi gedung. Setiap story dari konstruksi gedung pasti ada elemen pelat lantai. Oleh sebab itu, pelat lantai memegang andil yang besar dalam menentukan anggaran biaya bangunan tersebut karena volumenya yang besar dan masif. Dengan menggunakan pelat lantai yang efektif, anggaran suatu bangunan dapat ditekan sehingga biayanya dapat lebih kecil. Belakangan ini sedang ramai penggunaan pelat lantai flat slab. Flat slab adalah two way slab yang tidak menggunakan balok pada konstruksinya. Dengan tidak adanya elemen balok, keuntungan utamanya adalah dapat mengurangi tinggi lantai karena plafon akan lebih rendah sehingga tinggi bangunan total akan lebih rendah. Disisi lain, dengan tidak adanya elemen balok maka kolom akan langsung bertumpu pada pelat dan akan mengakibatkan konsentrasi tegangan pada daerah sekitar kolom. Maka diperlukan perkuatan pada pertemuan kolom pelat berupa drop panel. SNI 2847 -2013 mengatur bahwa tebal minimal drop panel adalah seperempat tebal pelat lantai dan panjang minimal drop panel adalah seperenam bentang. Dalam penelitian ini akan dianalisis struktur beton bertulang dengan tinggi $4 \mathrm{~m}$ dengan dimensi kolom $500 \mathrm{~mm}$ x $500 \mathrm{~mm}$ menggunakan drop panel dengan variasi panjang drop panel 800 mm, 900 mm, 1000 mm, $1100 \mathrm{~mm}$ dan $1200 \mathrm{~mm}$. Analisis akan dilakukan dengan metode elemen hingga bantuan software komputer. Nantinya akan dilihat hasil pengaruh penambahan panjang terhadap geser pons dan momen lentur yang terjadi.
\end{abstract}

Kata kunci : pelat lantai, two way slab, flat slab, drop panel, geser pons, metode elemen hingga.

\section{PENDAHULUAN}

\section{Latar Belakang}

Di zaman millennial ini, semua teknologi di berbagai bidang berkembang dengan sangat pesat. Baik teknologi di bidang telekomunikasi, bidang otomotif, dan masih banyak lagi. Tidak kalah canggih juga bidang konstruksi pun mengalami kemajuan yang sangat pesat. Karena tuntutan zaman dimana kebutuhan manusia makin beragam dan dengan jumlah dan skala yang besar, maka teknologi di bidang konstruksi dituntut untuk terus berkembang supaya dapat mengimbangi tingginya demand dari masyarakat.

Pelat adalah struktur tipis yang dibuat dari beton bertulang dengan bidang yang arahnya horizontal, dan beban yang bekerja tegak lurus pada bidang struktur tersebut (Asroni,2010). Pelat termasuk elemen struktur karena fungsi dari pelat ini adalah sebagai yang pertama menerima beban, baik dead load maupun live load yang kemudian baru disalurkan ke balok. Kebanyakan pelat lantai di gedung bertingkat di Indonesia masih menggunakan pelat konvensional yaitu pelat two way slab yang masih menggunakan elemen balok. Belakangan ini, konstruksi pelat dengan pelat cendawan ( flat slab ) mulai banyak digunakan pada konstruksi gedung. Flat slab adalah konstruksi pelat beton bertulangan tanpa menggunakan elemen balok. Karena hal itu, beban pada pelat akan langsung disalurkan ke kolom sehingga mengakibatkan akan terjadi konsentrasi tegangan yang besar pada daerah sekitar kolom yang sering disebut geser pons. Untuk menghindari kegagalan akibat geser pons maka pada struktur flat slab sering ditemui perkuatan pada daerah pertemuan pelat kolom berupa drop panel.

SNI : 2847 - 2013 menyatakan bahwa panjang minimal drop panel adalah seperenam jarak antar kolom. Pada penelitian ini akan difokuskan untuk melihat pengaruh ukuran drop panel terhadap nilai geser pons dan momen lentur. Lalu hasil analisis akan dibandingkan hasilnya dengan perhitungan manual teoritis sesuai SNI : 2847 - 2013. 


\section{Tujuan Penelitian}

Tujuan penelitian ini adalah untuk mengetahui pengaruh ukuran drop panel terhadap nilai geser pons dan momen lentur pada flat slab.

\section{Batasan Masalah}

Batasan masalah yang digunakan pada penelitian ini adalah analisis struktur digunakan dengan program komputer berbasis elemen hingga dengan kondisi struktur pelat lantai arah $\mathrm{x}$ dan arah y masing masing 4 bentang dengan jarak bentang 6 meter. Dimensi kolom yang digunakan sama yaitu 500 mm x 500 mm. Beban Super Dead Load ( SDL ) = $1.5 \mathrm{kN} / \mathrm{m}^{2}$ dan Live Load $(L L)=4.79 \mathrm{kN} / \mathrm{m}^{2}$. Ketebalan pelat yang digunakan adalah $200 \mathrm{~mm}$ dan tebal drop panel yang digunakan adalah $275 \mathrm{~mm}$ dan bentuk drop panel persegi. Tinggi kolom diambil 4 meter.

\section{TINJAUAN PUSTAKA}

Flat slab adalah konstruksi pelat beton bertulang tanpa balok yang sering digunakan dewasa pada konstruksi beton bertulang pada bangunan,seperti kantor,tempat tinggal,atau fasilitas insdustri lain nya dengan tinggi menengah (medium-rise office) karena effisiensi dari rasio bentang/tebal (span/depth ratios) dan segi ekonomis karena mengurangi tinggi lantai (Daniel dkk, 2016). Dikarenakan tidak adanya elemen balok maka akan terjadi konsentrasi tegangan pada daerah sekitar kolom yang jika tidak direncakanan dengan baik akan terjadi kegagalan geser pons pada daerah sekitar kolom.

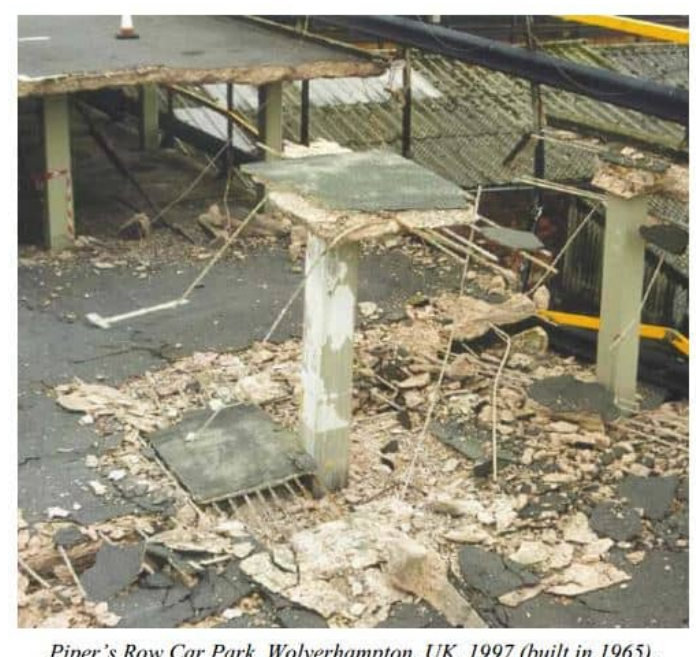

Gambar 1 Kegagalan Struktur akibat Geser Pons

(sumber : https://civildigital.com/punching-shear-punching-shear-flat-slabs/)

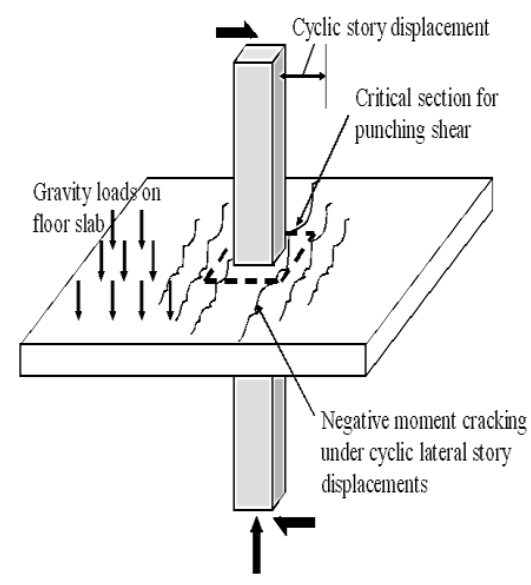

Gambar 2 Konsentrasi Tegangan di Pertemuan Kolom dan pelat (Jirsa,2009) 
Dikarenakan rawan akan terjadinya kegagalan akibat geser pons maka dari itu pada struktur flat slab sering dijumpai perkuatan berupa drop panel. SNI : 2847 - 2013 menyebutkan bahwa tebal minimal drop panel adalah seperempat tebal pelat lantai dan panjang drop panel minimal adalah seperenam bentang kolom.

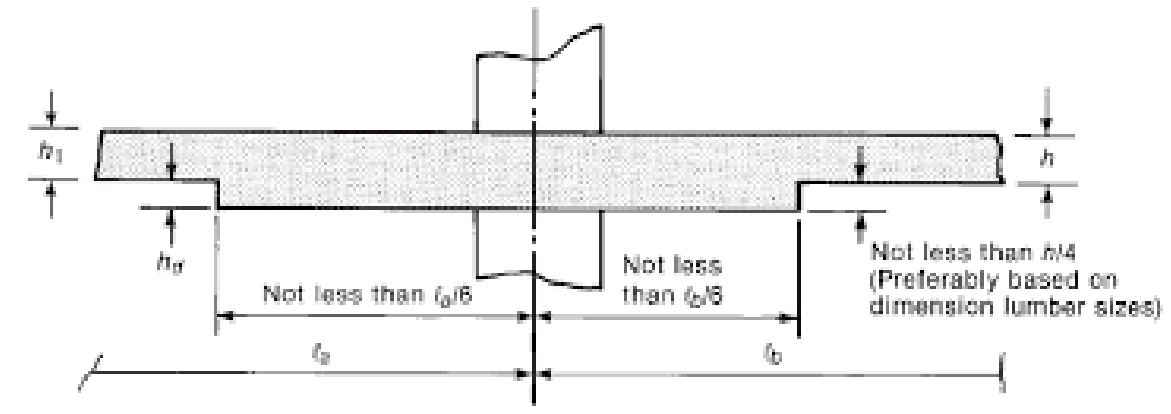

Gambar 3 Tebal dan Panjang Minimal Drop Panel

Sumber: Reinforced Concrete: Mechanics\&Design, James K. Wigh \& James P McGregor (2011)

Flat slab harus direncanakan dapat menahan tegangan geser pons akibat beban luar. Jika kapasitas beton menahan tegangan pons melebihi tegangan geser pons yang terjadi maka tidak diperlukan perkuatan geser pons. Berdasarkan SNI : 2847- 2013 tegangan geser pons dapat dihitung dengan rumus :

$$
\sigma_{u}=\frac{V u}{b_{o} \cdot d}+\frac{\gamma_{2} \cdot M_{2} \cdot C_{2}}{J_{2}}+\frac{\gamma_{3} \cdot M_{3} \cdot C_{3}}{J_{3}}
$$

Keterangan :

$$
\begin{array}{ll}
\sigma_{u} & =\text { Tegangan geser pons }(\mathrm{MPa}) \\
V u & =\text { Gaya geser yang dipikul } \operatorname{kolom}(\mathrm{N}) \\
b_{o} & =\text { Keliling kritis geser pada } \operatorname{kolom}(\mathrm{mm}) \\
d & =\text { Tebal efektif pelat }(\mathrm{mm}) \\
\gamma_{2} & =\text { Proporsi momen yang ditransfer menjadi tegangan geser } \\
M_{2} & =\text { Momen pada titik kolom yang ditinjau }(\mathrm{Nmm}) \\
C_{2} & =\text { Jarak dari pusat perimeter kritis geser } \operatorname{ke} \text { tepi } \operatorname{kolom}(\mathrm{mm}) \\
J_{2} & =\text { Momen inersia polar daerah perimeter } \operatorname{kritis} \operatorname{kolom}\left(\mathrm{mm}^{4}\right)
\end{array}
$$

Setelah didapat tegangan geser pons, hasilnya dibandingan dengan kapasitas tahanan geser beton yang diatur di SNI: 2847 - 2013 Pasal 11.11.2.1 yaitu nilainya diambil dari yang terkecil dari ketiga rumus dibawah ini :

$$
\begin{aligned}
& \sigma_{c}=0.17\left(1+\frac{2}{\beta}\right) \lambda \sqrt{f^{\prime} c} \\
& \sigma_{c}=0.083\left(\frac{\alpha_{s} d}{b_{o}}+2\right) \lambda \sqrt{f^{\prime} c} \\
& \sigma_{c}=0.33 \lambda \sqrt{f^{\prime} c}
\end{aligned}
$$

Keterangan :

$$
\begin{array}{ll}
\sigma_{c} & =\text { Tahanan geser beton ( MPa ) } \\
\beta & =\text { Perbandingan panjang dan pendek kolom } \\
\lambda & =\text { Koefisien untuk properti mekanis ( untuk beton biasa }=1 \text {, beton ringan }=0.75 \text { ) } \\
f^{\prime} C & =\text { Mutu beton ( MPa ) } \\
\alpha_{s} & =40 \text { untuk kolom interior, } 30 \text { untuk kolom tepi dan } 20 \text { untuk kolom sudut }
\end{array}
$$




\section{METODE PENELITIAN}

Langkah pertama yang dilakukan pada penelitian ini adalah melakukan studi literatur terlebih dahulu untuk memahami dasar dasar teori flat slab sehingga selama selama proses penelitian tetap pada teori flat slab sebelumnya. Lalu langkah selanjutnya adalah melakukan modelisasi pada software komputer dengan membuat denah, tinggi struktur pelat, dimensi pelat dan drop panel dan dimensi kolom. Lalu menginput beban yang bekerja beserta dengan kombinasi yang digunakan. Kombinasi yang digunakan adalah kombinasi service dan ultimate. Lalu setelah dirun dikumpulkan data data yang diperlukan berupa geser pons pada tiap kolom dan momen lentur pada setiap jalur. Setelah dikumpulkan semua data yang diperoleh, lalu langkah selanjutnya adalah melakukan pengolahan data untuk mencapai tercapainya tujuan penelitian. Denah struktur dibuat tipikal seperti yang terlihat pada Gambar 4. Langkah langkah pengerjaan secara umum dapat dilihat pada Gambar 5.

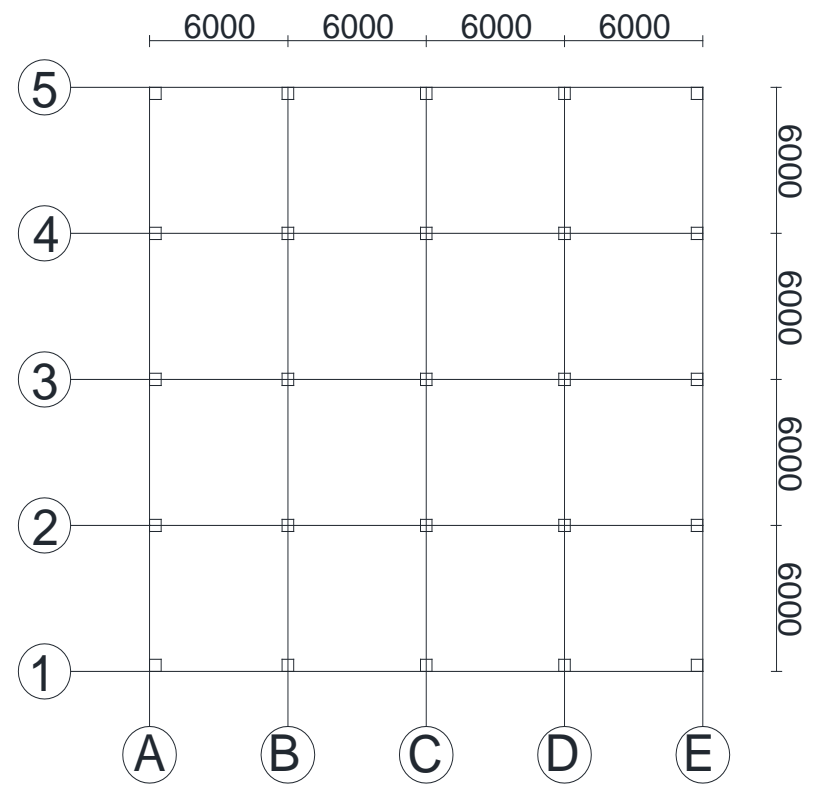

Gambar 4 Denah Struktur 


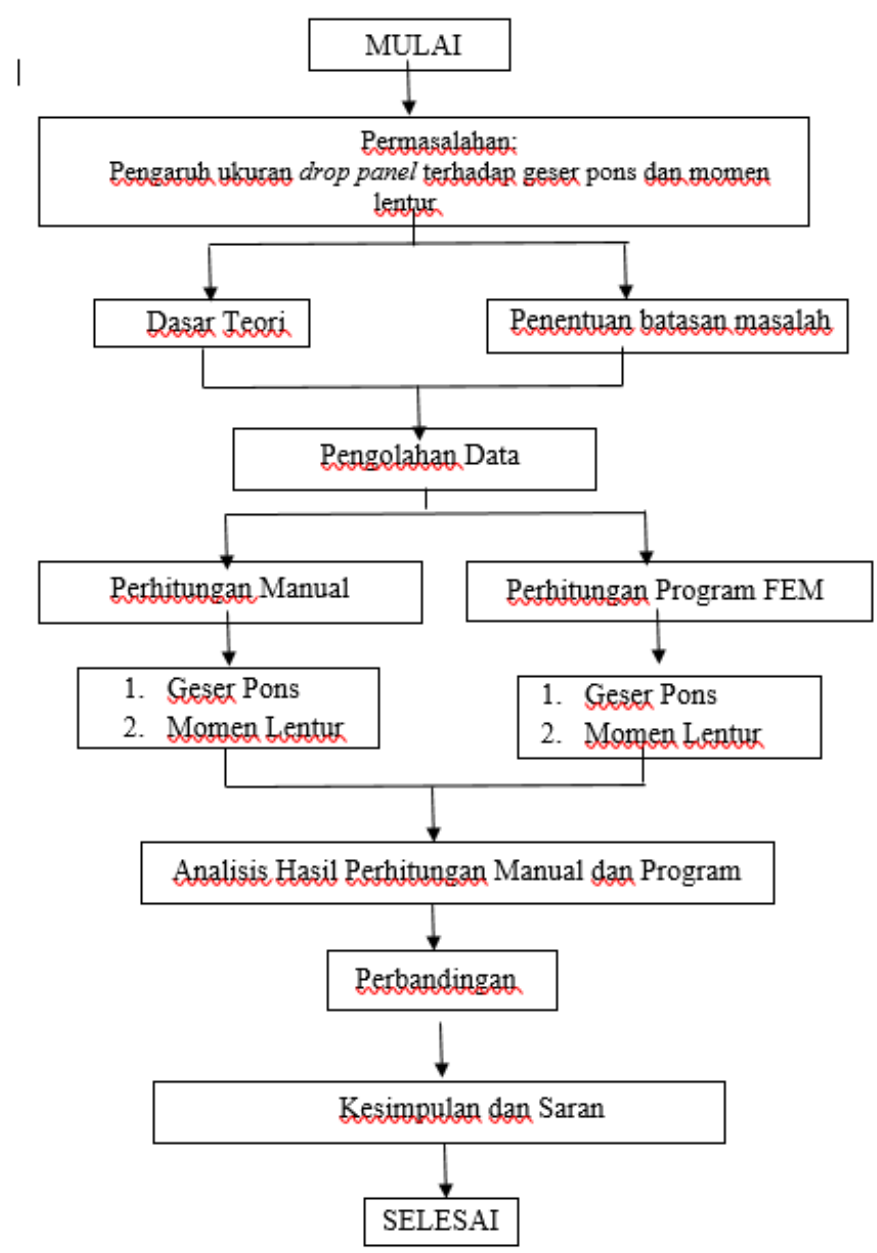

Gambar 5 Diagram Alir Penelitian

\section{STUDI KASUS}

Studi kasus dilakukan dengan memvariasikan ukuran drop panel untuk mengetahui pengaruh ukuran drop panel terhadap nilai geser pons dan momen lentur. Ada 6 model yang akan dianalisis yaitu :

- $\quad$ Model 1 = Tanpa drop panel

- $\quad$ Model 2 = Dengan drop panel dengan ukuran $160 \mathrm{~cm}$ x $160 \mathrm{~cm}$ untuk kolom tengah, $80 \mathrm{~cm}$ x $80 \mathrm{~cm}$ untuk kolom sudut

- $\quad$ Model 3 = Dengan drop panel dengan ukuran $180 \mathrm{~cm}$ x $180 \mathrm{~cm}$ untuk kolom tengah, $90 \mathrm{~cm}$ x $90 \mathrm{~cm}$ untuk kolom sudut

- $\quad$ Model 4 = Dengan drop panel dengan ukuran $200 \mathrm{~cm}$ x $200 \mathrm{~cm}$ untuk kolom tengah, $100 \mathrm{~cm}$ x $100 \mathrm{~cm}$ untuk kolom sudut

- $\quad$ Model 5 = Dengan drop panel dengan ukuran $220 \mathrm{~cm}$ x $220 \mathrm{~cm}$ untuk kolom tengah, $110 \mathrm{~cm}$ x $110 \mathrm{~cm}$ untuk kolom sudut

- $\quad$ Model 6 = Dengan drop panel dengan ukuran $240 \mathrm{~cm}$ x $240 \mathrm{~cm}$ untuk kolom tengah, $120 \mathrm{~cm}$ x $120 \mathrm{~cm}$ untuk kolom sudut 
Berikut contoh ilustrasi struktur flat slab dan detail drop panel untuk flat slab model 2 :

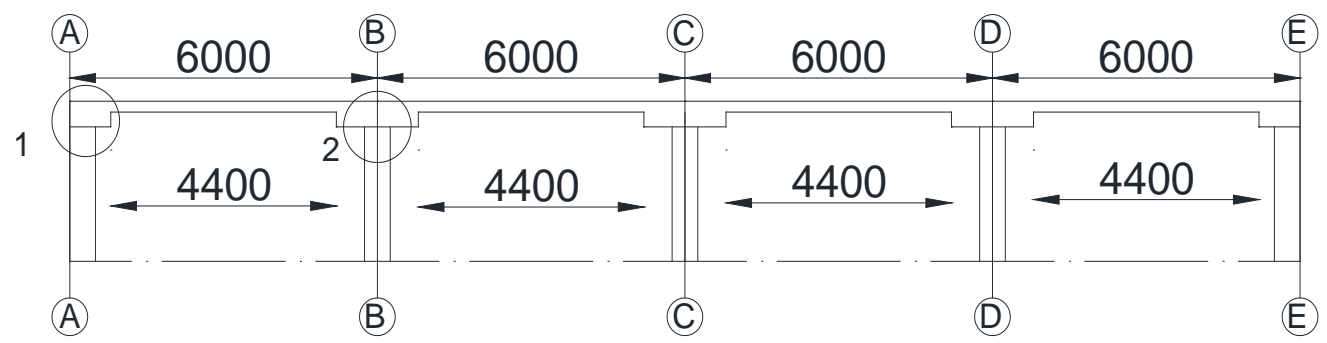

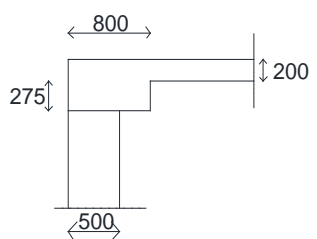

DETAIL DROP

PANEL 1( UNIT $\mathrm{MM}$ )

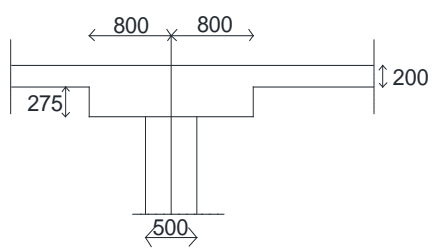

$$
\begin{aligned}
& \text { DETAIL DROP } \\
& \text { PANEL } 2 \text { ( UNIT } \\
& \text { MM ) }
\end{aligned}
$$

Gambar 6 Detail Drop Panel model 2

Analisis momen lentur hanya akan dilakukan pada SA1, SA2, SA3, SA4 dan SA5 serta pada Span 1 dan Span 2 karena dengan bentangan dan beban yang simetris hasil momen lentur bersifat simetris seperti yang dapat dilihat di Gambar 7. Sedangkan untuk mempermudah analisis geser pons, kolom dikelompokan menjadi 6 tipe :

- $\quad$ Kolom tipe 1

- $\quad$ Kolom Tipe 2

- Kolom Tipe 3

- Kolom Tipe 4

- Kolom Tipe 5

- Kolom Tipe 6
$=$ Kolom 1,6,22,26

$=$ Kolom 3,5,7,11,17,21,23,25

$=$ Kolom 4,12,16,24

$=$ Kolom 8,10,18,20

$=$ Kolom 9,13,15,19

= Kolom 14 


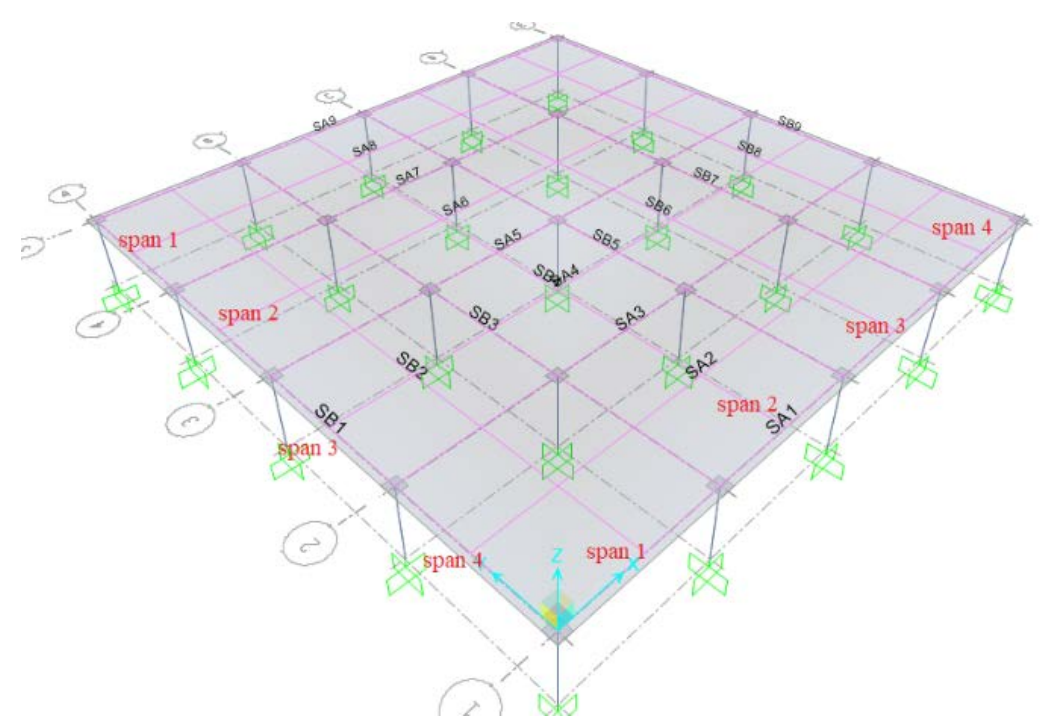

Gambar 7 Penamaan Jalur Pelat Lantai

Untuk penomoran kolom dapat dilihat seperti pada Gambar 8

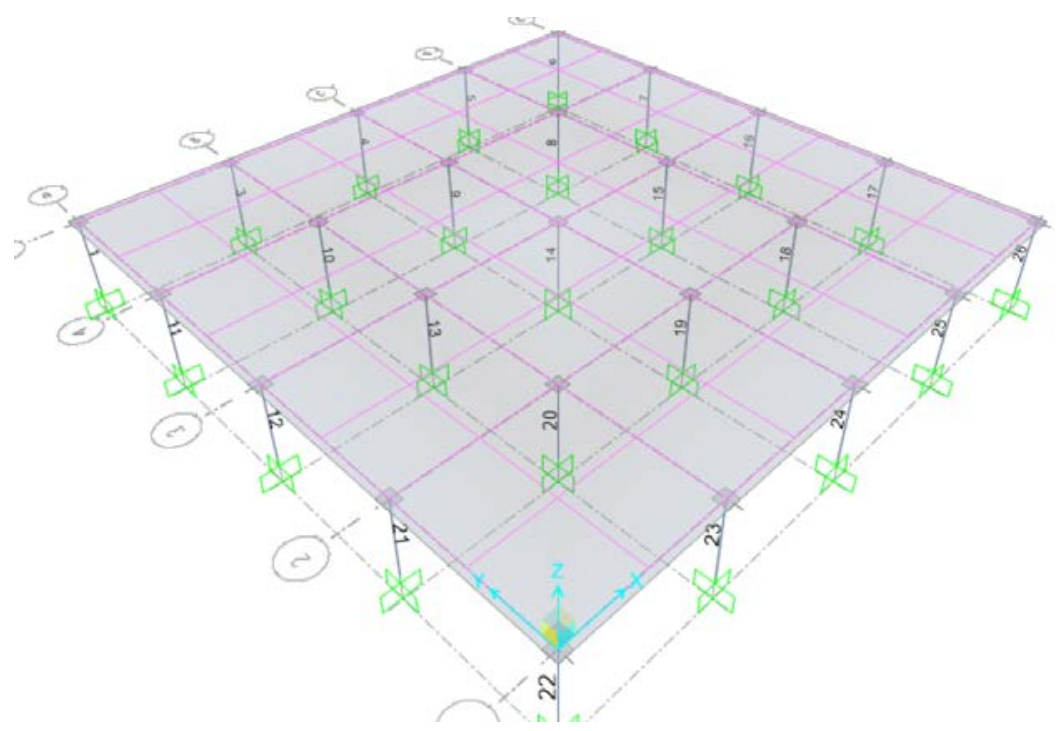

Gambar 8 Penomoran Kolom

Hasil analisis menunjukan dengan bertambah besarnya ukuran drop panel momen yang diserap pada daerah tumpuan menjadi semakin besar. Hal tersebut dapat dilihat di Gambar 9 yang menunjukan pertambahan momen pada SA1 Span 2. Dikarenakan hasil yang seragam maka hanya akan ditampilkan grafik pertambahan momen tumpuan pada SA1 Span 2. 


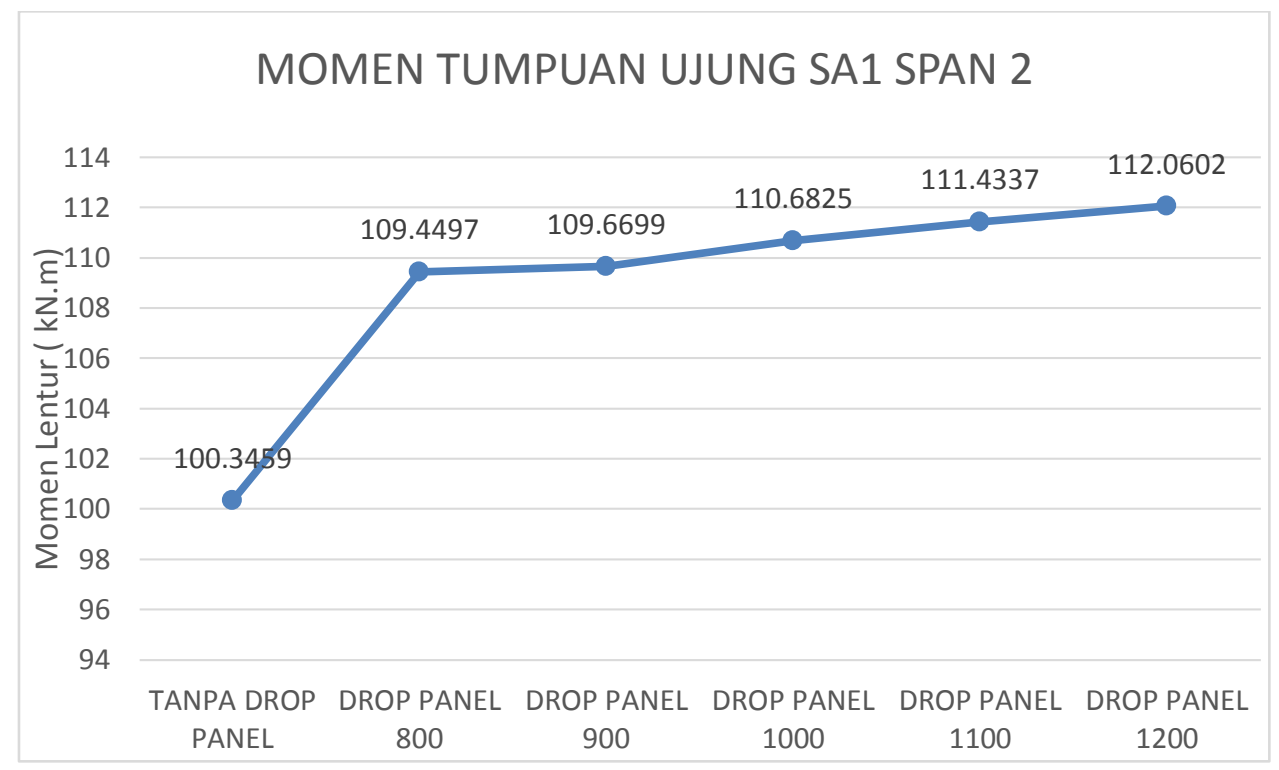

Gambar 9 Grafik Momen Tumpuan SA1 Span 2

Sedangkan untuk momen pada daerah lapangan menunjukan hal yang sebaliknya, yaitu bertambahnya ukuran $d r o p$ panel menyebabkan momen lapangan berkurang seperti yang ditunjukan pada Gambar 10 yang menunjukan momen lapangan pada SA1 Span 2.

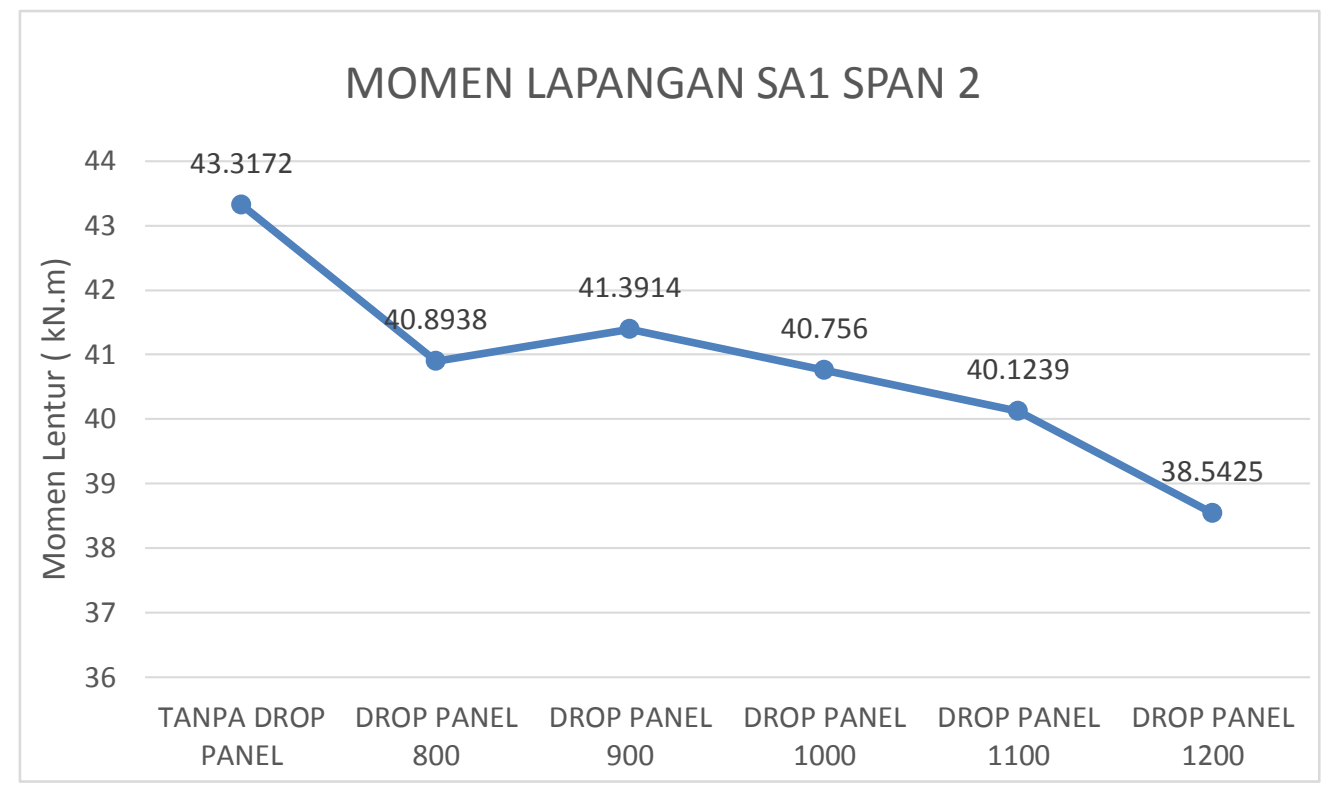

Gambar 10 Grafik Momen Lapangan SA1 Span 2

Sedangkan untuk pengaruh ukuran drop panel terhadap nilai geser pons dapat dilihat pada Gambar 11. Pada Gambar 11 ditunjukan grafik punching shear ratio tipe kolom 1. Punching shear ratio adalah perbandingan nilai tegangan geser pons dibandingkan terhadap nilai kapasitas tahanan geser beton sendiri. Jika nilainya melebihi satu, artinya terjadi kegagalan geser pons pada kolom tersebut. Untuk perancangan, struktur flat slab harus dirancang sedemikian rupa supaya tahan terhadap geser pons sehingga selama perancangan nilai punching shear ratio tidak boleh melebihi batas kegagalan ( nilai punching shear ratio melebihi 1).

Dari Gambar 11 dapat dilihat bahwa pertambahan ukuran drop panel tidak memberikan dampak yang signifikan terhadap nilai punching shear yang terjadi tetapi penggunaan drop panel memberikan efek yang signifikan dalam mereduksi geser pons seperti yang bisa dilihat di Gambar 11 bahwa nilai punching sheari turun drastis dari model 1 ( tanpa drop panel ) ke model 2 (dengan drop panel ukuran $160 \mathrm{~cm}$ x $160 \mathrm{~cm}$ ). 


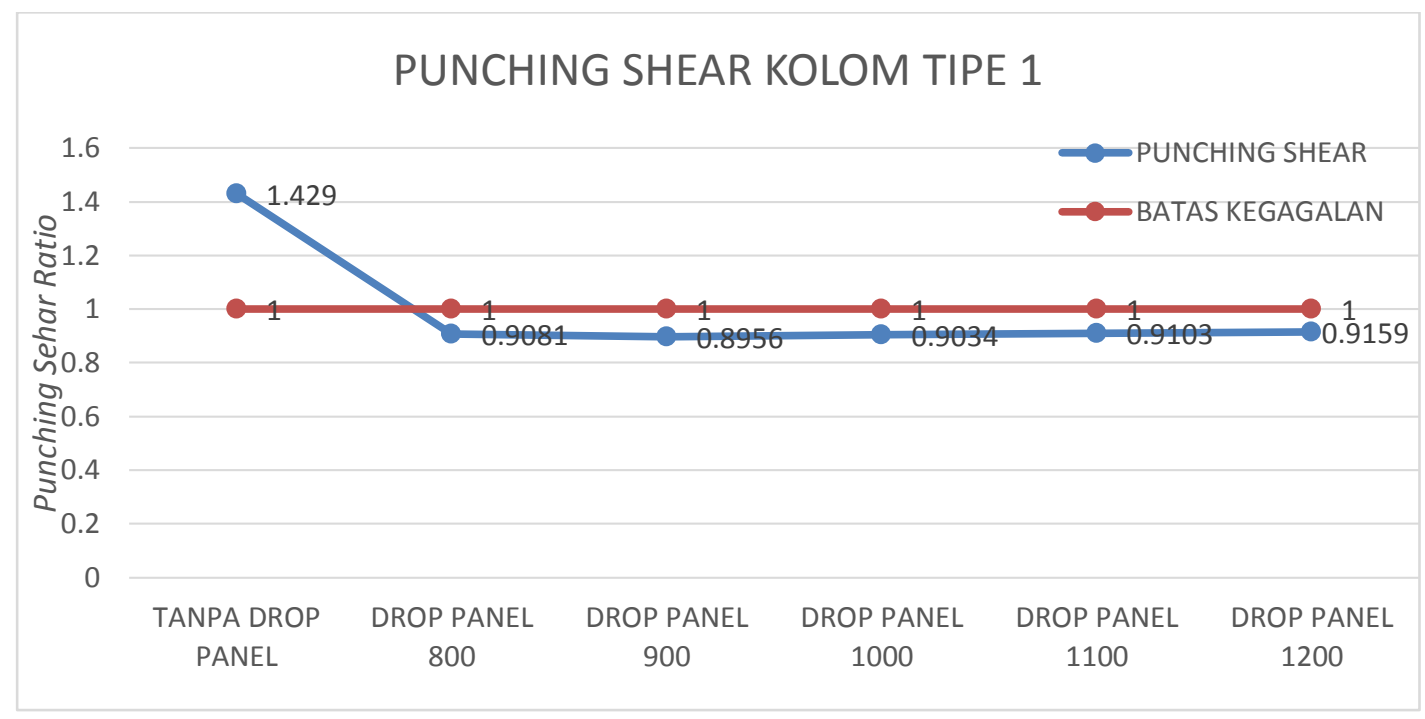

Gambar 11 Grafik Punching Shear Kolom Tipe 1

\section{KESIMPULAN DAN SARAN}

\section{Kesimpulan}

Berdasarkan hasil analisis didapatkan kesimpulan sebagai berikut :

1. Hasil analisis dengan metode elemen hingga ( finite element method ) memiliki perbedaan sebesar rata rata $4 \%$ pada analisis momen lentur dengan metode rangka ekivalen dan memiliki perbedaan sebesar rata rata $3.5 \%$ pada analisis tegangan geser pons dengan metode SNI.

2. Penggunaan drop panel pada struktur pelat flat slab efektif untuk mereduksi tegangan geser pons pada flat slab. Hal ini dibuktikan dengan menurunnya secara drastis nilai punching shear ratio dari model tanpa drop panel ke model dengan drop panel pada setiap tipe kolom.

3. Pertambahan panjang drop panel tidak terlalu signifikan mempengaruhi nilai geser pons yang terjadi.

4. Semakin panjang dimensi drop panel, momen lentur yang dihasilkan pada daerah tumpuan akan bertambah besar. Hal ini disebabkan karena semakin bertambahnya panjang drop panel maka daerah tumpuan akan semakin kaku dan mengakibatkan momen lentur akan terserap lebih ke daerah tumpuan sebaliknya momen pada daerah lapangan akan berkurang.

\section{Saran}

Supaya hasil penelitian selanjutnya dapat lebih akurat dan lebih mewakili struktur flat slab pada kenyataannya, berikut saran dari penulis untuk penelitian selanjutnya :

1. Untuk penelitian selanjutnya dicoba memperhitungkan beban gempa.

2. Untuk penelitian selanjutnya juga dicoba dimodelkan tulangan pada pelat supaya hasil penelitian bisa lebih akurat.

\section{DAFTAR PUSTAKA}

Asroni, Ali. (2010). Balok Dan Pelat Beton Bertulang, Penerbit Graha Ilmu,Yogyakarta.

Badan Standardisasi Nasional. (2013). SNI 2847-2013: Persyaratan Beton Struktural Untuk Bangunan Gedung. Jakarta.

Badan Standardisasi Nasional. (2013). SNI 2847-2013: Beban Minimum untuk Perancangan Bangunan Gedung dan Struktur lain. Jakarta.

Ervianto, D., Indryani, R., \& Wahyuni, E. (2012). Studi Perbandingan Pelat Konvensional, Ribslab dan Flatslab Berdasarkan Biaya Konstruksi. Jurnal Teknik POMITS Vol. 1, No. 1, (2012) 1-5. 
Jirsa, J.O. (2009). "Determination of Critical Shear, Moment, and Deformation Interactions For RC Slab- Column Connections”, Structural Engineering, The University of Texas, Austin.

MacGregor, James. dan James K. Wight. (2011). Reinforced Concrete: Mechanic \& Design Sixth Edition. New Jersey: Pearson.

McCormac,Jack C. (2001). Desain Beton Bertulang Edisi Kelima Jilid 1 dan 2. Jakarta: Erlangga.

Micallef, K. dkk. (2014). Assesing Punching Shear Failure in Reinforced Concrete Flat Slabs Subjected to Localised Impact Loading, International Journal of Impact Engineering. 17-33.

Sathawane, A.A., \& Deotale, R.S. (2012). Analysis and Design of Flat Slab and Grid Slab and Their Lost Comparison.International Journal of Advanced Technology in Civil Engineering ISSN : 2231-5721.

Sunggono. (1984). Buku Teknil Sipil.Penerbit : Nova.Bandung.

Tambusay,Asdam,dkk. (2014). Studi Eksperimental Perilaku Hubungan Pelat Kolom Menggunakan Drop Panel dengan Serat PVA-ECC terhadap Beban Siklik Lateral.Konferensi Nasional Pascasarjana Teknil Sipil (KNPTS).

Teruna,D.Rumbi \& Prawira,Stanley. (2017). Studi Perbandingan Penggunaan Flat Plate dan Flat Slab dengan Drop Panel Struktur Bangunan Ditinjau Dari Segi Volume.Jurnal USU Vol.6, No. 1. 